\title{
HMGA2/COX6C Fusion Protein
}

National Cancer Institute

\section{Source}

National Cancer Institute. HMGA2/COX6C Fusion Protein. NCI Thesaurus. Code C99431.

A fusion protein encoded by the HMGA2/COX6C fusion gene. This protein is comprised of the AT-hook DNA binding domain of the high mobility group protein HMGI-C fused to the C-terminal half of the cytochrome c oxidase subunit $6 \mathrm{C}$ protein. 